\title{
Provincialising Heidegger; Globalising Arendt
}

\section{Manu Samnotra*}

\begin{abstract}
Dipesh Chakrabarty's Provincializing Europe uses Martin Heidegger's Being-with to ground his defence of a decolonial historiography. In this essay I show that Heidegger's broader aims within Being and Time nullify Chakrabarty's hopes for recovering fragile political spaces. In contrast to Heidegger, I propose Hannah Arendt's writings on Jewish politics as an alternative for students of decolonisation. Arendt's focus on plurality and new beginnings complement Chakrabarty's critiques of historicism and political belonging in a way that more fully realises the broader ambitions of Provincializing Europe.
\end{abstract}

Keywords: Martin Heidegger; Hannah Arendt; Jewish Politics; Historicality; Being-With.

Peace has been said to be indivisible; so is freedom, so is prosperity now, and so also is disaster in this one world that can no longer be split into isolated fragments. To the people of India, whose representatives we are, we appeal to join us with faith and confidence in this great adventure. This is no time for petty and destructive criticism, no time for ill-will or blaming others. We have to build the noble mansion of free India where all her children may dwell.

\section{Jawaharlal Nehru}

\section{Speech to the Constituent Assembly, 14-15 August 1947}

This essay brings Dipesh Chakrabarty's Provincializing Europe into dialogue with the political thought of Hannah Arendt. This proposed dialogue would help students of Provincializing Europe recover a neglected political feature of the post-colonial experience. This political feature concerns a form of provincialisation that is coeval with building new political institutions. This is because, and as Jawaharlal Nehru's remark at the moment of Indian independence indicates, the post-colonial moment is as much a continual negotiation between the (traditional) past and the (modern) future as it is premised on a break, rather than continuity, in historical precedents. Chakrabarty's version of provincialisation demands attentiveness from the historian to subjectivities forged in the encounter betwe-

* University of South Florida, Tampa-FL, United States; msamnotra@usf.edu. 
en modernity and tradition. This method helps the contemporary actor identify spaces of freedom from under the pall of historicist ${ }^{1}$ thinking. Arendt's approach provides an indispensable addendum to this motivation. Arendt helps us see how new beginnings are fundamentally conjoined to the experience of political freedom. In Arendt's thought, freedom is more than just the articulation of negative liberties; freedom is also a collective capacity to responsibly engage the weight of the historical past through the creation of new political institutions.

The proposed dialogue between Chakrabarty and Arendt is connected by the very different positions they each take with respect to Martin Heidegger's Being and Time. Chakrabarty's hopes of discovering 'plural ways of being in the world' draw upon Heidegger's existential analytic in Being and Time, especially the status of Dasein as a Being-with (Chakrabarty 2000: 101). While acknowledging Chakrabarty's adoption of his thought, I argue that Heidegger himself is a thinker waiting to be 'provincialized.' Heidegger's notion of being-in-the-world is nested within two broader aims. ${ }^{2}$ The first of these is to explicate how Dasein's finitude opens the possibility for a more authentic engagement with the historical tradition. Second, and relatedly, the historical consciousness that resolutely takes up authentic existence does so only through an agonistic engagement with others who have come to face their own finitude. As Walter Brogan notes, 'death... is the constitutive existential mark of Da-Sein [and] is the precondition for a philosophy of community that remains faithful to the utter singularity and finitude of each of the members of the human community' (Brogan quoted in Raffoul and Pettigrew 2002: 237). I argue that Heidegger's concern with an individual's finitude is antithetical to the project of excavating a socially inflected post-colonial political consciousness.

In contrast, Arendt directed her energies towards revitalising the political 'now' in ways that were critical of Heidegger's approach. Arendt's writings on Jewish politics and resistance during the Second World War and after parallel in important ways Chakrabarty's own stance on the task of provincialising Europe. The parallel between the two voices in this proposed dialogue is enabled by Arendt's role, as a journalist and political historian, to break the shackles historicism had imposed on the Jewish population in both Europe and abroad. Unlike Chakrabarty, Arendt saw the challenge of combating historicism not only in the historical excavations of political spaces long since occluded under European categories, but also in the creation of these spaces from the prism of an ethically charged political present. In her expectant opening towards the creation of new forms of political belonging (both domestically and internationally), she outlines a conception of political Being-with that is simultaneously dependent upon and a departure from Heidegger's thought. In this sense, Arendt's departure is an important addition to Chakrabarty's analysis.

The implication of reading Chakrabarty and Arendt together and against Heidegger is that the project of provincialising Europe is shown to depend on both tracing historical developments that broke free from European categories and generating attentiveness to the element of praxis that attends moments of liberation (be they from colonial rule or Nazi occupation). While Chakrabarty himself sees the leaders of post-independence In- 
dia and the Non-Aligned movement as hopelessly caught in the trap of a technological/ developmentalist orientation, Arendt's reading of the political would direct a researcher to critically engage the discourse and strategies employed by postcolonial leaders in the very moment of complete freedom. A consequence of this attentiveness would be that, where Chakrabarty, possibly following Heidegger himself, creates an implicit binary between the tradition-modernity translation on the one side and statist modernity on the other, the Arendtian reading would ask us to see in the moment of creating political institutions the very apogee of a form of translation trying to break free of historicist expectations. Becoming attentive to this moment of translation helps the reader to recover not only a form of subjectivity that is perhaps lost to history and cynicism, but also ways in which translation and politics might reside much closer to each other than Chakrabarty seems to suggest.

\section{Problematising Heidegger}

The ethical gesture underwriting Chakrabarty's non-teleological analysis is undoubtedly Heidegger's development of Being-with. In this section, I deepen Chakrabarty's presentation of Being-with by showing its connection to the issue of temporality. As a number of Heidegger's commentators note, the linkage between these two aspects of Being and Time is a site for much contestation (Visker cited in Critchley and Dewes 1996). Principally, the connection questions the kind of politics Heidegger's thought sanctions. While Heidegger's involvement with National Socialism generates a lot of heated opinions about the political message of Being and Time, I will bracket these very important questions. My aim in this essay is to see how Chakrabarty uses these concepts, and how Arendt might address his conclusions. In what follows, I dispense, therefore, and along with Chakrabarty himself, the question of whether Heidegger's thought is irredeemably National Socialist (Chakrabarty 2012). My aim in this section is to show how embedded within the concept of Being-with a fundamental relationship to temporality, finitude, and authenticity is, which Chakrabarty fails to address in his appropriation of Heidegger's thought.

Being-with underwrites some of the fundamental features of Chakrabarty's argument. Chakrabarty argues that the idea of modernity in the colonial and post-colonial context is not necessarily a reflection of European modernity. Colonial modernity is inflected through the existing structures and relationships that govern colonial and traditional life. Indeed, modernity emerges precisely in the encounter between the modern and the traditional. This encounter is never solely pedagogic, wherein modernity 'teaches' traditionalism its error (Chakrabarty 2005). There is a dialogue and contestation between modes of conduct, and this dialogue and contestation gives rise to particular subjectivities. An obvious example here is Chakrabarty's analysis of the capitalist, but decidedly non-bourgeois Indian family. The ties of kinship and the status of women within the male hierarchy prevent the development of a bourgeois self. In its stead, the individual subjectivity navigates, and is created through, the traffic between traditional kinship and capitalist relations. This element of Being-with through which colonial modernity is wrought in India would be 
inaccessible through a purely historicist politics of progress that discounted the continued valence of kinship structures.

If Being-with is such an important feature of Chakrabarty's analysis, it would behove us to turn to this aspect of Heidegger's thought. Developed primarily in Division I of $\mathrm{Be}$ ing and Time, Heidegger's Dasein (the investigator of Heidegger's universe) is always a Being-with, that is, she exists in the world with others and inhabits this world with them through a tradition of meaning. Yet, the traditions that provide Dasein with the meanings upon-which she acts can also distract her from her 'potentiality-for-being.' ${ }^{3}$ This is because it is easy to unthinkingly absorb the accepted ways of interpreting the world. Everything becomes, to use a phrase Chakrabarty regularly borrows from Heidegger, 'ready-to-hand' As Chakrabarty notes, 'ready-to-hand' indicates 'the everyday, preanalytical, unobjectifying relationships we have to tools, relationships critical to the process of making a world out of this earth' (Chakrabarty 2000: 68). For Heidegger himself, this relationship is fundamental to the experience of the world. These 'everyday, preanalytical, unobjectifying' relations provide us with the grounds upon which we are able to act. Furthermore, these relations also equip us with 'fore-ceptions' about anticipated futures that seem to arise from the structures of understanding and meaning upon-which we act.

Although Chakrabarty does not say this, for Heidegger himself, this preanalytical state is really a condition of 'fallenness'. This does not mean that it is in any hierarchical sense lesser than the experience of making something 'present-at-hand', i.e., engaging something at an analytical level. 'Fallenness' helps us experience both history and a sense of identity as we move through the world. We are at every moment already 'fallen'. This also does not imply that fallenness is the only option available to Dasein. To turn once again to Visker, that 'fallenness' 'is both embedded in Dasein's structure of Being and that it can and should be overcome is precisely the problem Being and Time struggles with' (Visker quoted in Critchley and Dewes 1996: 67; emphasis in original). The encounter with finitude through the silent voice of conscience enables resoluteness in the face of an essentially open future. ${ }^{4}$ That is to say, Dasein's orientation towards the world around her is not always dependent on routinised ways of acting. Instead, and as Francoise Dastur notes, 'the silence of the call [of conscience is] to be inscribed within the dimension of a selfhood that exists always according to the mode of a promise to oneself, that is, according to the mode of a constancy of oneself... which has nothing to do with the substantiality of an ego' (Dastur quoted in Raffoul and Pettigrew 2002: 94). In resoluteness, Dasein does not escape the world, but stands in a more authentic relationship to it. As de Beistegui argues, this reorientation 'is not an inward movement whereby Dasein would cut itself off from the world so as to enjoy the peace and depth of some precious inner life. Rather, it is a movement of disclosure, of clearing, where Dasein authentically ek-sists its own essence, and this means confronts its own facticity' (de Beistegui 1998: 15).

The recovery of authenticity is described in Division II of Being and Time such that authenticity assumes a temporal character. Where Being-with in Division I is concerned with describing Dasein's embeddedness in relationships with the world, Division II shows the historical character of these relationships. In other words, the parallel development 
of Being-with in Division I transforms into a discussion of historicality in Division II. For Heidegger, historicality is a more primordial experience of time than that which is available to us via scientific apparatuses (the time of physics, say), and historiographies. When Heidegger directs sustained attention to the concept of historicality (in Chapter 5, Division II of Being and Time), he frames his discussion within the broader question of the 'meaning of the Being of Dasein's totality' (Heidegger 2010: 356). How is it, in other words, that a being framed by birth and death is able to maintain a sense of identity such that she understands herself as the same being in year one, two, three... until now? The answer to this question can only be answered by understanding how time functions. Any access to an understanding of time must occur through the ground upon-which human agents base their conduct. In other words, by understanding how time functions, we also gain insight into the nature of Being as it is available to a historically embedded agent. This is the essentially disclosive nature of human Dasein. Put differently, by turning her attention (care/Sorge) to different aspects of her life, Dasein brings to light the meaning upon which she was acting. The fact that this disclosure is always historical does not mean that it is handed down to the actor as a pre-existing given. Precisely because it is historical, the meaning upon-which the actor acts is always changing, and the actor contributes to the maintenance and change of that tradition of meaning. History is alive because both the past and the future are being constantly maintained and interpreted anew.

This is where Chakrabarty primarily draws his analysis of 'fragmentariness' and the 'not-yet'. The historically embedded Dasein is always oriented towards an expectant future (the 'not-yet'). This, indeed, is the very heart of Dasein's disclosive capacity as someone who is a Being-in-the-world, and not someone who, in the manner of Cartesian philosophy, inhabits a space alongside other beings. This futural capacity, because it is historically derived and interpreted anew, is always in flux and fragmentary. This is the core conceptualisation of History 2 that Chakrabarty sketches so beautifully. For instance, in the context of his discussion of capital in Marx's thought, Chakrabarty designates History 2 as 'a category charged with the function of constantly interrupting the totalizing thrusts' of historicism (Chakrabarty 2000: 66). The fragmentary nature of individual expectations that are generated through Dasein's embedded nature as a being who is always Beingwith allows the contestation of historically totalising narratives of human development, be these Marxist, national-developmentalist, etc.

While Chakrabarty's analysis is undoubtedly correct, it is important to remain attentive to the Heideggerian terrain from which Chakrabarty draws his conclusions. Beingwith, fallenness, fragmentary futures, and the futural expectations of Dasein are all interconnected. Joining them together is Heidegger's insistence that Dasein must 'pull itself together from the dispersion and the disconnectedness of what has just "happened"' (Heidegger 2010: 371; emphasis in original). As Chakrabarty notes, 'the history "of the many," was always directed at submerging Dasein by imposing on it an ultimately fragmenting temporal structure from the outside' (Trüper, Chakrabarty and Subrahmanyam 2015: 15). We have already seen how conscience plays a role in reorienting Dasein's relationship to her present. Let us retrace the steps in this transformation. 
The reorientation towards 'what has just happened', i.e., towards history itself, becomes activated through existential anxiety. According to Hubert Dreyfus, Heidegger's concept of anxiety is a secularised version of Kierkegaardian philosophy (Dreyfus 1991: 304). In Heidegger's adoption of the term, anxiety arises at moments when, in attempting to decipher the appearance of something unexpected, Dasein finds established forms of interpretations inadequate. This notion of anxiety is crucial to Chakrabarty's own analysis of the birth of modern subjectivity in Bengal. For instance, the contestation between the modes of prose and poetry that occurred in early twentieth-century Bengal attest to an agonism about the proper way to portray the anxieties stemming from life in a capitalist metropole. But where Chakrabarty locates this anxiety in its factual form as a response to the appearance of something new (the advent of urban modernity), for Heidegger, Dasein is not an entity that is the sum total of its experiences, as if these experiences could be tallied in advance or retrospect to give Dasein its totality. Instead anxiety individualises Dasein (she has to recognise her own potentiality) and is brought 'back from its absorption in the "world". Dasein discovers that she is 'not-at-home' (Heidegger 2010: 182; emphasis in original). In Jacques Taminiaux's interpretation, 'the world in the authentic sense is announced when the stability and the safety of the environment have been shaken and reduced to nothingness, as when tools break down or are revealed inadequate to the task at hand' (Taminiaux 1997: 13). The orientation of the world shifts from being 'ready-tohand' to becoming 'present-at-hand'. And it is this sense of being not-at-home vis-à-vis the world that creates an opening for Dasein's authentic encounter with her own potentiality. Again, even in anxiety, Dasein never steps outside the historical tradition. As a fundamentally temporal being, Dasein cannot quit the world. Instead, the conscience that anxiety births transforms Dasein's internal orientation to the world.

Conscience has the power to pull Dasein away from her immersion into 'fallenness', and open up temporality. As Heidegger notes, 'Only being free for death gives Dasein its absolute goal and pushes existence into its finitude. The finitude of existence thus seized upon tears one back out of endless multiplicity of closest possibilities offering themselves - those of comfort, shirking and taking things easy - and brings Dasein to the simplicity of its fate [Schicksals]' (Heidegger 2010: 365; emphasis in original). Heidegger calls the acceptance of a finite individualised future 'fate'. However, Dasein is always also Being-with '... if fateful Dasein essentially exists as being-in-the-world in being with others, then its occurrence is an occurrence-with and is determined as destiny [Geschick]' (Heidegger 2010: 366; emphasis in original). While the individual Dasein's historicality is termed as fate, its potentiality to be a transformative force remains inaccessible without a corresponding sense of destiny (Geschick).

The transformation of fate into destiny is fundamentally dialogic, but is also disclosed agonistically. 'Communicating and struggling', allow Dasein to revisit the original principles that underwrote her community, and in this 'reciprocative rejoinder/repetition' (Erwidert) she discovers that the original principles were themselves an-archic. As Peg Birmingham notes, 'the event of destiny... disturbs a narrative politics by breaking narratives of legitimation based on tradition and a simple identification with the past... Dasein's 
critical response dissolves any authorization of repeatable historical possibilities based on a myth of beginnings' (Birmingham 1991: 31). This means that the origin upon-which tradition legitimises itself is revealed to be the greatest point of freedom where what seemed like fatedness is reinterpreted as a new destiny. But this new opening towards the origin becomes available to Dasein only when she communicates and struggles with those Others who have accepted their fate as finite beings. ${ }^{5}$

I would be remiss in this description of Heidegger's thought without mentioning explicitly that this sense of embeddedness in time is what he ultimately means by historicality. And the sense of historicality that emerges from Destiny is not oriented towards the past or even the present, but arises from Dasein's future (Heidegger 2010: 367). This idea seems very close to the heart of Chakrabarty's analysis and prescription for provincialising Europe. As he notes, in encountering the remnants of the past, 'there is... no "desire for going back," no "pathological" nostalgia that is also not futural as well. Being futural is something that is with us, at every moment, in every action that the human being undertakes' (Chakrabarty 2000: 250). This unavoidable sense of the future itself has two components. The first is a sense wherein one imagines the future to see what 'will be' (as say, politically modern, Marxist, etc.). This sense of the future is what is bequeathed to us by what Chakrabarty calls History 1 . The second is a sense of the future that already, through traditional practices, laces the present of the investigator. ${ }^{6}$ This is History 2. Chakrabarty tells us that this second sense of the future 'does not necessarily look to the future that "will be," which forms in the calculations and desires of the subject of political modernity' (Chakrabarty 2000: 251). Instead, this sense of the past exists as a plurality of the senses of the future that interlace the present of an investigating actor. Much like the communication and struggle of Heidegger's Destiny, this pluralised and fragmentary form of the future shapes and reshapes the meaning of political modernity from inside the consciousness of the actors engaged in it.

\section{The contemporaries of destiny}

It is easy to see how Chakrabarty adopts futurity in its Heideggerian guise to excavate the development of post-colonial subjectivities. The Bengali women who contested their roles within the indigenous forms of 'bourgeois' life, the men who gathered in the adda for tea and conversation, even the political leaders who saw in their discovery of India traces of world spirit, all of these were always engaging vestiges of the past actualised in their own actions and those of their contemporaries. In other words, even in the act of breaking from the past, these actors were in some sense maintaining its continuity. The question that emerges from this analysis, however, and as I hope to show presently, relates directly to politics. What sort of politics does this Heideggerian reading sanction and, more importantly, does this politics adhere to Chakrabarty's own aims of breaking free from teleological models of political development?

In its agonistic form, politics is contestation. In the series of tensions Chakrabarty highlights (between poesy and prose, between males and females, etc.), politics arises 
precisely in the fragile space opened up by such contestations. These contestations are not simply sociological developments that occurred independently of the political realm. They did, and continue to, by way of political movements, bridge questions of what Chakrabarty calls 'translation' and 'social justice. That is to say, these contestations not only occur on the micropolitical level within the family, or via new subjectivities, but also relate to grand political moments. And it is precisely of this later sense of contestation that Heidegger remained wary. Heidegger himself classes such contests as departures from the existential mission of Dasein (individually) and a 'people' (collectively). For him, 'the polis cannot be defined 'politically.' The polis, and precisely it, is therefore not a 'political' concept' (Heidegger quoted in Kisiel in Raffoul and Pettigrew 2002: 154). In contrast to Heidegger, it is Arendt who advances the best vision of a politics oriented around Heideggerian categories, but one not subject to his rejection of politics as 'fallenness'.

The turn to Arendt is itself laced with problems for scholars interested in employing her for post-colonial perspectives. As a series of writers have pointed out, Arendt's problematic analysis of colonialism either explicitly or implicitly (depending on how one reads her) reproduces racist and colonial hierarchies (Dossa 1980; Norton 1995; Bernasconi 2007; Klausen 2010; Mantena 2010). Regardless of the strength of these claims, by focusing on her Jewish writings I not only hope to bracket her problematic thoughts on colonialism and the history of racism, but more importantly, I rely on a line of investigation that links the European Jewish experience with the experience of subalterity within the colonial context (Mufti 2009). Since this is not the place to offer an exhaustive overview of Arendt's thought, I will limit myself to a couple of items. First, I will focus on her engagement, during the course of the Second World War, with the ongoing Holocaust and military resistance within this context. Second, from this set of writings I want to draw an important point of difference between her and Heidegger. Arendt's conceptualisation of the political is broader than that offered by Heidegger, and therefore adds an important element - that of new beginnings - to Chakrabarty's aim of provincialising Europe.

Born into an assimilated Jewish family in Germany in 1906, Arendt saw the continuity of her upbringing and education shattered with the rise of Nazism and her subsequent escape from Germany. During the course of the Second World War, Arendt anxiously scoured news reports about the unfolding situation in Europe. As the stories of the brutalities inflicted by the Nazis found their way to the United States, the scope of the humanitarian crisis became daily more apparent to her. It is with the cascading shock these brutalities produced that Arendt penned some of her most impassioned words. She writes in 1942:

Those people who do not make history, but simply suffer it, tend to see themselves as victims of meaningless, overpowering, inhuman events, tend to lay their hands in their laps and wait for miracles that never happen (Arendt 2007: 241).

Embedded within these powerful lines is Arendt's scathing assessment of not only the decline of Jewish historiography, but the tragic acceptance of anti-Semitic and national- 
ist historicism by Jews themselves. In a lengthy essay that prefigures many of the themes she later developed in the section on anti-Semitism in Origins of Totalitarianism, Arendt argued that 'in the hands of assimilationists Jewish history was turned into a history of the injustice inflicted on us, that lasted until the end of the eighteenth century, when... it merged into world history' (Arendt 2007: 48; emphasis in original). The advent of the Nazis, seen through the prism of Zionists and those who, like centuries of Jewish thinkers, had come to see oppression as an inevitable state of affairs, would brook no resistance. The Holocaust becomes in this historicist lens nothing but the fruition of trends centuries in the making.

It is no surprise then that Arendt, in an almost Heideggerian vein, argues in 1944, if you do not accept something that assumes the form of 'destiny', you not only change its 'natural laws' but also the laws of the enemy playing the role of fate' (Arendt 2007: 223). To accept Jewish history as assimilationists, Zionists, and anti-Semites have narrated it is to foreclose the possibilities for action. For, if the advent of Nazism is seen as nothing but the consummation of 'natural laws', resistance is completely futile. There is nothing to be done but to lament the 'meaningless, overpowering, inhuman events', and wait for miracles to deliver the oppressed. In contrast, in a world where a certain fate seems unavoidable, questioning what appears as destiny unlocks the historical narrative that seems to lead inevitably to one predetermined end. Such questioning helps the actor rediscover her agency - which, in Arendt's thought itself, is always something we share with others and with it the capacity for the miraculous.

On one level, the thought Arendt presents here seems to share many properties with the Heideggerian discourse on fate and destiny I outlined in the previous section. This semblance, however, is only skin-deep. The most telling example of Arendt's reconfiguration of fate into destiny occurs in a moment of militarised resistance against Nazi occupation. Where for Heidegger repetition signals a break in the narrative structure of Dasein and a return to the an-archic origin, Arendt's account of repetition means replaying the historical trends of anti-Semitism 'just with pluses and minuses reversed' (Arendt 2007: 222). This does not imply that anti-Semitism is folded back to its origins, or that the antiSemitic insight is fundamentally correct (even if its historical delivery is faulty). Rather, Arendtian repetition is utterly new because it gives rise to actions unforeseen by historicist expectations. As such, the actions that unfold from this repetition do not recover the past and interpret it anew. Rather, they stand on the very ground of the unexpected.

To deepen our understanding of the Arendtian shift in repetition, fate, and destiny, let us turn to an example of this reconfigured repetition/rejoinder. Arendt highlights the miraculous solidarity between anti-fascist partisans and Jewish resistance groups. Writing as a contemporary of these events, and with an eye towards provoking armed resistance against Nazi occupation, she argues that this solidarity followed a pattern that was the complete reversal of what had transpired at the start of the war. Where Vichy France had easily transferred its Jewish refugees to the occupying German forces, the changed situation in 1944 is reflected in the decision of the French Maquis - the guerrilla resistance group - to break off vital prisoner transfer negotiations the moment it became clear that 
the Nazis wanted to exclude Jews from within the ambit of any agreement. 'Even considerations of expediency', Arendt notes, 'could not bring these Frenchmen to recognise a 'special destiny' for Jews' (Arendt 2007: 224). The past in this case is no guide to action in the present. Indeed, the past only points the way towards expediency. Moreover, the actions of the Maquis cannot in any sense be seen as a recovery of a latent capacity within the European tradition either. It is utterly new. In its Heideggerian guise, the pull of tradition as the very ground upon which meaning is built - even in the moment of its narrative interruptions - remains largely unbroken. This is because, and as we saw in the previous section, Dasein searches for constancy between its birth and death. Within the context of which Arendt writes, reciprocative rejoinders that hark back to a past in order to interpret it anew are altogether impossible. Instead, the repetition of history with 'pluses and minuses reversed' points to politics and freedom, both of which arise only when the 'thread of tradition is broken' (Arendt 1977: 212).

Arendt's engagement with the identity of the political actor constitutes an utter departure from the Heideggerian source. Where, for Heidegger, it is a community (however defined) of agonistic engagement with tradition, for Arendt, plurality is the sine qua non of politics. This means that the community of the polis is birthed in action. Nothing unites the Maquis and the refugees on whose behalf they fight except the promise of a new beginning together. This is the miracle of political action, and its products cannot be anticipated in advance. Indeed, even the expectation of its failure would foreclose its promise. There is no finitude in death against which the actor recoils into politics.

Taken together these two points constitute a political departure from Heidegger's thought. For Arendt, plurality and natality constantly add to the stream of actors who, each of them, take the burden of political action anew. The polis exists only when new actors, be they Maquis or Jewish refugees, take up the challenge of acting in the face of a complete breakdown of tradition. More importantly, through her invocation of plurality, Arendt locates the response to the end of tradition within a political sphere. As we saw, for Heidegger the polis is the tradition of historical co-existence, not its political institutions. Arendt reintroduces into this understanding of the polis its actively political dimensions.

Arendt's unyielding attachment to an unwritten future paradoxically institutionalised within a polis underlines her commitment to natality, i.e. new beginnings. In contrast, the whole cultural and historical matrix that Heidegger develops in Division II of Being and Time as a complement to his hermeneutics would dissolve if we did not take his insistence on finitude as our starting point. As already noted, this finitude allows the repetition/reciprocative rejoinder to the tradition, and thereby unlocks its inherent, although historically untapped, potentiality. But what if this historical tradition has revealed itself to be bankrupt, as it did to a host of Jewish thinkers wrestling with the aftermath of the Holocaust?

A similar question bedevilled Arendt, although her answer is not transhistorical in the sense that it consigned European thought to the dustbin of history. Rather, for her, plurality is a way out of the historical morass European thought found itself in, whose greatest thinkers could either only stand the received tradition on its head (Marx, Nietzsche, 
Kierkegaard), or remained forever shy of the political implications of the new era birthed by the Holocaust. In contrast, the possibilities available to each new individual - although conditioned by the historical circumstances of her birth - can never be foreclosed in advance. This is because this natality connotes 'the new beginning inherent in birth can make itself felt in the world only because the newcomer possesses the capacity of beginning something anew, that is, of acting' (Arendt 1998: 9). As such, for Arendt, the birth of new subjectivities is always more important than the Heideggerian focus on finitude, especially when the past has ceased being a guide to the future. It seems to me that, much more than the 'fragmented' possibilities of the 'not yet', it is plurality (and natality) that open the space for the politics Chakrabarty asks social scientists to appreciate.

\section{The descent into errancy: or politics}

Even if the foregoing analysis is accepted, it still does not answer the question of what it would mean for students of Provincializing Europe to turn from Heidegger to Arendt. In closing, let me take up this question directly. I noted earlier that Arendt herself offers a space for thinking politically in line with Chakrabarty's own ethical expectations. This expectation is expressed, albeit negatively, in another of Chakrabarty's writings. In an essay devoted to the Non-Aligned movement (NAM) and the failures of post-independence leaders to rethink development strategies apart from the dictates of the USA-Soviet binaries, Chakrabarty highlights the teleological expectations inherent in the developmentalist visions of NAM leaders (Chakrabarty 2005). Such a teleological expectation necessarily gave rise to a pedagogical mode of conversation between the advanced NAM leaders (Nehru is here again a principal exemplar) and the post-colonial masses in need of direction.

For Chakrabarty, the thinking expressed by NAM leaders, beholden as it was to the logic of developmentalism, reveals the truth of Heidegger's later thesis about the sway of technology. Unable to separate itself from technology, Mankind cannot even the pose the question of its relationship to technology but in technological terms. While Heidegger's essay certainly does express Chakrabarty's concerns with post-independence developmentalist teleologies, there is another Heidegger essay that, perhaps unwittingly, shares the tragedy of the NAM's political and imaginative failures in the way Chakrabarty diagnoses them. Turning to this essay brings to the fore the element of new beginnings, and the praxis that is called forth by it, that Chakrabarty himself seems to ignore in his historical excavations.

In an essay he wrote immediately at the conclusion of the war, Heidegger turned attention to a Greek fragment, traditionally attributed to the philosopher Anaximander (Nietzsche 1962: 45-46). ${ }^{7}$ The issue that drives Heidegger's engagement with this text can be encapsulated in his question whether 'we stand in the very twilight of the most monstrous transformation our planet has ever undergone, the twilight of that epoch in which earth itself hangs suspended' (Heidegger 1973: 580). This question is not surprising given that Heidegger poses it in 1946, at the end of the Second World War. 
What is surprising is that with this question Heidegger announces a seemingly radical shift away from the project outlined in Being and Time. No longer is the experience of authentic temporality rooted in historicality, which is accessed as a common destiny between co-struggling actors. In its stead, Heidegger advances a bleak thesis: everything we call history is an error; history indicates not the history of Being, but its departure. 'Error', as Heidegger directly states, 'is the space in which history unfolds' (Heidegger 1973: 591).

In order to understand Heidegger's tragic vision of history and its relationship to the argument advanced in this chapter, it is important to briefly survey what Heidegger is trying to say. According to Heidegger, everything that appears came from and will return to the realm of concealment. In this move, Heidegger condenses both points of finitude (our birth and our deaths) into one. Once things emerge from this original concealment, they seek to 'tarry', 'linger' in the realm of appearance. In their sheer presence, however, things blind us to Being. We might understand Heidegger as saying that once we begin to focus on things, we lose sight of the wholeness of Being of which things are a part. This way of thinking is what, ultimately, led Western philosophy into metaphysics and the elevation of the human perspective as the apogee of philosophical rumination. While this certainly signals the birth of philosophy, the tarrying of things in the realm of unconcealment also creates the possibility of an original justice/injustice. Everything is in error, because everything takes the space of another, and nothing that exists can justify its eruption from non-Being into Being.

The suggestive lines of inquiry broached in Heidegger's text are, in Arendt's estimation, of signal importance to Heidegger's thought. From a political perspective, the text signals, according to Arendt, a 'changed mood [that] reflected Germany's defeat, the "point zero"... that for a few years seemed to promise a new beginning' (Arendt 1977: 188). Although never formally developed by either Heidegger or Karl Jaspers - whose speech in Geneva Arendt mentions approvingly (Arendt 1977: 189) ${ }^{8}$ - this promise of a new beginning was soon dashed, as Arendt puts it, 'in the rapidity of German economic and political recovery from "point zero"' (Arendt 1977: 189). It is as though, in Arendt's universe, the quality of pariahdom that had visited Germany was forgotten too soon in the exigencies imposed by a Cold War mentality. The 'point zero' that Arendt speaks of here has similarities to other revolutionary moments that she came to celebrate. In this moment the insuperable lineages of historical development seemed to have broken down. Not only was tradition no longer a sure guide to the post-war present, but it was palpably felt by philosophers such as Jaspers and Heidegger to offer an opening onto a new political and philosophical orientation.

Although Arendt does not call Heidegger an Idealist - she did reserve the epithet 'last great romantic' (Arendt 2005: 187) for him - it is clear that she classes such thinking as a philosophical attempt to escape the abyss of political life. In the essay on the Anaximander fragment, Arendt sees Heidegger's evasion in the philosophical task he sets himself of "lingering for a while" in the present realm of errancy... through the thinking activity, [the philosopher joins himself] to what is absent' (Arendt 1977: 193-194). What is left, as Arendt reads Heidegger, is the impulse to relieve the self of 'this realm of error [which] 
is the sphere of common human history, where factual destinies are connected and form a coherent shape through "erring"' (Arendt 1977: 192). I would suggest that what Arendt lauds in Heidegger is not so much the product of his thinking, her comments on which she calls 'tentative in the extreme', but the fact that the philosophical mind attuned to 'epochal' thinking became aware of the new epoch that dawned with the end of the Second World War and the complete destruction of Nazi Germany. However, by reducing even this epochal transformation to another iteration of 'errancy', Heidegger lost sight of the profound changes that this 'point zero' had created in its wake.

We might ask whether such a critique is not also what animates Chakrabarty's own analysis of Bandung and the promises surrendered in the aftermath of decolonisation. Certainly, Chakrabarty's Heideggerian assessment that the process of decolonisation is the "last phase in the history of... "the Europeanization of the earth"' (Chakrabarty 2005: 4815) rings true. Post-colonial states sought to effect decolonisation in terms that were, more or less, beholden to European categories (Zarakol 2011). On the other hand, in a Heideggerian reading the very nature of this Europeanisation - and even any alternatives that we might conceivably imagine - is tainted with fallenness and errancy. Heidegger's own mode of analysis would foreclose the space for politics precisely in those spaces where Chakrabarty would direct our gaze. Arendt's critique of this Heideggerian tendency is therefore a necessary caveat to Chakrabarty's reliance on Heidegger.

Like Chakrabarty, Arendt too sees the trajectory of political movements beginning at a 'point zero' as open-ended, but nearly always tarnished by historicist expectations. Whether she speaks of the ultimate failures of the American Revolution to escape the allure of the past, or the inability of the Jerusalem court where Adolf Eichmann stood trial to see the fullest scope of his crimes (Arendt 2006), Arendt always worried about how historical narratives diminished our ability to encounter the new and the unexpected. I believe in this Arendt shares Chakrabarty's fears and tragic vision. However, where Heidegger seems to provide Chakrabarty with the language of technological enframing (Gestell), Arendt would serve a different purpose. First, Arendt shows that even within Heidegger's discussion of technology there hides his broader eschewal of political beginnings. Second, not only does her definition of political belonging depart from Heidegger's notion of errancy, it also provides the antithesis to the Eurocentric tragedy of a movement such as NAM. Let me offer in closing, for readers interested in Arendt, one instance of this line of thinking.

As I have already noted, scarred by the experience of exile, and the rise of totalitarian governments, Arendt located the seed of many of the worst tendencies of the nineteenth century - anti-Semitism, Imperialism, and Totalitarianism - in the rise of nationalism. To counter this tendency, she cautioned the newly formed state of Israel against following the model of the European nation-state. In its stead, she advocated the formation of ' $a$ kind of Mediterranean federation' (Arendt 2007: 197; emphasis in original) that would, rather than seek the recognition and help of former colonial masters, turn to 'the national revolutionary peoples of Asia in their struggle against imperialism' (Arendt 1994: 366). This federative structure would not be shorthand for a new empire, but a genuine commonwealth. 
Although cynicism may cast a harsh light on Arendt's appeal to both Arabs and Jewish settlers in Palestine, she shares much the same vision as what would later inspire the leaders of NAM: the hope that the 'tryst with destiny' - the words with which Nehru inaugurated the birth of independent India - disclosed in the point-zero of the post-war/post-colonial environment is not squandered to seemingly inevitable historical trajectories. However, rather than engage the Heideggerian premise that such actions are necessarily acts of 'errancy', Arendt's political vision focuses on the promise of new beginnings. She transforms, therefore, the pathos of the moment of independence or peace into a call for praxis.

It is in this sense that her approach has much to offer students of Provincializing Europe. The element of praxis, which in Being and Time is indissociable from Dasein's escape from fallenness, is in Arendt transformed into a broader and open-ended political project, a praxis that, unlike its Aristotelian forerunner, is emptied not only of teleological expectations (Villa 1995) but also of the element of traditionalism (European or otherwise) that hampered the fullest exercise of political freedom in the aftermath of war or colonisation. While we with the benefit of hindsight might approach her concrete political suggestions with healthy scepticism, her exuberance deserves attention. The praxis of independence, just as much as the translation that continually effects the passage to a provincial modernity, points the way towards the fragile link between translation and politics. In the very act of beginning anew the political actor translates against a backdrop of traditional expectations and the opportunities that the new moment represents.

In Chakrabarty's thought this moment heralds the birth of a new subjectivity. From an Arendtian perspective the more important moment is when this subjectivity is given institutional articulation. At this moment the political actor widens the ambit of translating tradition into modernity. Not only is it an action she partakes in with others of her generation, but she also allows future generations to take it up anew. In a manner of speaking, the political act of founding new institutions gives birth to a truly open-ended tradition of action and meaning. In this way, provincialisation becomes a facet of the polis itself that is continually enacted by each successive actor. This is why, and despite the failures of post-independence political leaders in their domestic or transnational avatars, the historian or the political scientist should become attentive to the utterly new promise heralded in transformative moments. It is precisely in these transformative moments that the principle of politics achieves its highest articulation, and it is one for which no one, not even European history, has any template.

\section{Notes}

1 Following Michael Hardt's lead, I will leave it to historians to debate whether Chakrabarty's discussion of historicism is accurate. See Hardt 2001.

2 I am leaving aside for the purposes of this essay the broadest aim identified by Heidegger: Of recovering the question of Being itself.

3 In other words, the outcome of our appearance into the world is irreducible to the sociological, psychological, and physical attributes we have. As thrown beings, we are also involved in projecting forwards into the future, and it is the potentiality-for-Being that constitutes our freedom; we are not completely given over to the situation in which we enter the world. Although we are free in an existential sense, following what 
Heidegger calls the 'facticity' of our Being, we can say that the social and historical matrix into which we were born determines even our plans for the future. This is why Heidegger refers to Dasein as 'thrown possibility'.

4 I am thinking here of the obvious objection that the existential idea of finitude owes its existence to the very important role Martin Luther played in the formation of Heidegger's early thought. In addition, the devastating experiences of the First World War gave birth to a completely new account of finitude that affected thinkers besides Heidegger. Absent Luther and the First World War, one might reasonably ask whether Heidegger's insistence on finitude need play such an important role in our engagement with the colonial and post-colonial world. As will, I hope, become apparent presently, the indisassociable link between Division I and II of Being and Time is not merely a matter of interpretive fidelity to Heidegger. This link is at the heart of the historicality of the contemporary that Chakrabarty wants modern political scientists and historians to cultivate.

5 It is important to note here, along with de Beisteigui, that because Heidegger's analysis is ontologically overdetermined, it is ontically always political. As de Beistegui frames the question, what does it mean for a community as a whole to be oriented towards its own finitude? Wouldn't this collective experience - reminiscent of das man - destroy the very individualising effect that resoluteness towards finitude is supposed to bestow on Dasein? While de Beisteigui does not himself take up the issue, it is possible that Heidegger's politics is oriented around an account of arête (excellence) which can be shown only by a few. So while Heidegger's pronouncement might not lend itself to National Socialism, it might be more in line with an aristocratic account of politics. Chakrabarty, of course, would not subscribe to this line of thinking at all. He would instead liken it, correctly, to the pedagogic mode of politics practised by post-colonial leaders such as Nehru.

6 Chakrabarty here gives the example of the poet Arunkumar Sarkar, who identifies his desire for writing poetry in his love of language. This love was bequeathed to him from the religious incantations of his parents and Grandmother. As Chakrabarty reminds us, there is no necessary notion of writing poetry that links this religious past to the future desire to write poetry. The 'now' of the child listening to these incantations is fragmented and thus futurally open.

$7 \quad$ There are several different translations of this fragment, and Heidegger is careful to offer several of these. That being said, he notes quite early in this piece that a literal translation 'is not necessarily faithful'.

One translation, offered by Nietzsche in his Philosophy in the tragic age of the Greeks, reads:

Whence things have their origin, there they must also pass away according to necessity; for they must pay penalty and be judged for their injustice, according to the ordinance of time.

Heidegger is not pleased with this translation, because for him, it reveals Nietzsche's own attachment to the thesis of 'the will to power'. A literal translation, which Heidegger himself provides, reads:

But that from which things arise also gives rise to their passing away, according to what is necessary; for things render justice and pay penalty to one another for their injustice, according to the ordinance of time.

8 Arendt quotes from Jaspers' text, which reads: 'We live as though we stood knocking at gates that are still closed... what happens today will perhaps one day found and establish a world.'

\section{References}

Arendt, Hannah. 1977. The life of the mind. Houghton Mifflin Harcourt. 1994. The origins of totalitarianism. Houghton Mifflin Harcourt. 1998. The Human Condition. Margaret Canovan (ed). University of Chicago Press. 2005. Essays in Understanding, 1930-1954: Formation, Exile, and Totalitarianism. Jerome Kohn (ed). Schocken Books.

2006. Eichmann in Jerusalem: A Report on the Banality of Evil. Introduction by Amos Elon. Penguin. 
2007. The Jewish Writings. Jerome Kohn and Ron H Feldman (ed). Schocken Books.

Bernasconi, Robert. 2007. 'When the Real Crimes Began: Hannah Arendt's The Origins of Totalitarianism and the Dignity of the Western Philosophical Tradition'. In Richard H King and Dan Stone (eds), Hannah Arendt and the uses of history: imperialism, nation, race, and genocide. Berghahn Books, New York. pp. 54-67.

Brogan, Walter. 2012. 'The Community of Those Who Are Going to Die'. In François Raffoul and David Pettigrew (eds), Heidegger and practical philosophy. SUNY Press.

Chakrabarty, Dipesh. 2000. Provincializing Europe: Postcolonial Thought and Historical Difference: Postcolonial Thought and Historical Difference. Princeton University Press.

2005. 'Legacies of Bandung: decolonisation and the politics of culture'. Economic and Political Weekly: 4812-4818.

2012. 'Radical Histories and Question of Enlightenment Rationalism: Some Recent Critiques of Subaltern Studies.' In Vinayak Chaturvedi (ed), Mapping Subaltern Studies and the Postcolonial (Mappings Series). Verso Books.

Dastur, François. 2012. 'The Call of Conscience: The Most Intimate Alterity'. In François Raffoul and David Pettigrew (eds), Heidegger and practical philosophy. SUNY Press.

De Beistegui, Miguel. 1998. Heidegger \& the political: dystopias. Routledge.

Dreyfus, Hubert L. 1991. Being-in-the-world: A Commentary on Heidegger's Being and Time, Division I. MIT Press.

Dossa, Shiraz. 1980. 'Human Status and Politics: Hannah Arendt on the Holocaust'. Canadian Journal of Political Science / Revue Canadienne De Science Politique 13(2): 309- 323.

Hardt, Michael. 2001. 'The eurocentrism of history'. Postcolonial Studies: Culture, Politics, Economy 4(2): 243-249.

Heidegger, Martin. 2010. Being and time. Translated by Joan Stambaugh. Revised and with a Foreword by Dennis J Schmidt. SUNY Press.

. 1973. 'Martin Heidegger: The Anaximander Fragment'. Translated by David Farrell Krell Arion 1(4): 576-626.

Kisiel, Theodore. 2012. 'In the Middle of Heidegger's Three Concepts of the Political'. In François Raffoul and David Pettigrew (eds), Heidegger and practical philosophy. SUNY Press.

Klausen, Jimmy C. 2010. 'Hannah Arendt's Antiprimitivism'. Political Theory 38(3): 394-423.

Mantena, Karuna. 2010. 'Genealogies of Catastrophe: Arendt on the Logic and Legacy of Imperialism'. In Seyla Benhabib (ed), Politics in dark times: encounters with Hannah Arendt. Cambridge: Cambridge University Press. pp. 83-112.

Nietzsche, Friedrich Wilhelm. 1962. Philosophy in the Tragic Age of the Greeks. Washington, DC: Regnery Publishing.

Norton, Anne. 1995. 'Heart of Darkness: Africa and African Americans in the Writings of Hannah Arendt'. In Bonnie Honig (ed), Feminist interpretations of Hannah Arendt. University Park: Pennsylvania State University Press. pp. 247-262.

Taminiaux, Jacques. 1997. The Thracian Maid and the Professional Thinker: Arendt and Heidegger. State University of New York Press. 
Trüper, Henning, Dipesh Chakrabarty and Sanjay Subrahmanyam (eds). 2015. Historical Teleologies in the Modern World. Bloomsbury Publishing.

Villa, Dana. 1995. Arendt and Heidegger: the fate of the political. Princeton University Press.

Visker, Rudi. 1996. 'Dropping - the "Subject" of Authenticity: Being and Time on Disappearing Existentials and True Friendship with Being'. In Simon Critchley and Peter Dews (eds), Deconstructive subjectivities. SUNY Press.

Zarakol, Ayse. 2011. After defeat: how the East learned to live with the West. Vol. 118. Cambridge University Press.

\section{Acknowledgements}

Cheryl Hall, Sarah Pemberton, Peter Funke, Darcie Fontaine, and Alec Dinnin provided excellent advice on an earlier draft of this paper. I am grateful to two anonymous referees. Narendran Kumarakulasingam encouraged me throughout to bring my work on Arendt and Heidegger into closer dialogue with post-colonialism. Thanks also to the interim editor Jimmy Casas Klausen whose exceptional contributions to political theory continue to show me the way forward with my own work. Finally, I would like to express my gratitude to Naeem Inayatullah. His gnomic mentorship over the many years we have known each other has helped me find my own unsteady feet.

\section{About the author}

Manu Samnotra is an Assistant Professor at the University of South Florida, Tampa. He received his BA from Ithaca College, his MA from the New School for Social Research, and his PhD from the University of Florida. His research connects the political thought of Hannah Arendt with questions of post-colonial identity and politics. He is currently working on a book-length manuscript that examines how Arendt's political theory might help us recover the politically salubrious dimensions of shame. He is also concurrently conducting research that would bring continental philosophy and political theory into closer dialogue with the political thought of M K Gandhi and B R Ambedkar.

Received on 10 January 2016, and approved for publication on 12 August 2016.

\section{(cc) BY-NC} https://creativecommons.org/licenses/by-nc/4.0/ 